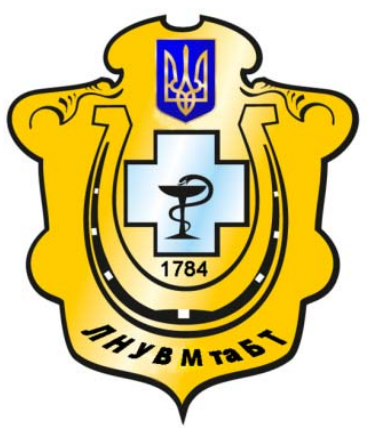

Науковий вісник Львівського національного університету ветеринарної медицини та біотехнологій імені С.3. Гжицького

Scientific Messenger of Lviv National University of Veterinary Medicine and Biotechnologies named after S.Z. Gzhytskyj

doi:10.15421/nvlvet6642

ISSN 2413-5550 print

ISSN $2518-1327$ online

$\underline{\text { http://nvlvet.com.ua/ }}$

УДК 619:616.24-002.153:615.015.32:636.7

\title{
Оцінка фармакологічної ефективності траумелю (ad us.vet) та фосфору-гомаккорд (ad us.vet) при бронхопневмонії собак
}

\author{
Ю.О. Чубов, В.Ю. Кушнір \\ ogsi@te.net.ua \\ Одеський державний аграрний університет, \\ вул. Пантелеймонівська, 13, м. Одеса, 65012, Украӥна
}

\begin{abstract}
Слизова оболонка респіраторного тракту легко піддається безпосередньому впливу навколишнього середовища, контактуючи із повітрям, яке вдихається, тому бронхопневмонія у собак зустрічається часто. Для терапії собак, хворих на катаральну бронхопневмонію, існує значна кількість засобів і методів, але вони не завжди є ефективними. Більш того, значна частина иих методів володіє тривалим періодом очікування дії та значною кількістю побічних ефектів. Тому метою наших досліджень був пошук ефективного та біологічно безпечного методу лікування собак, хворих на катаральну бронхопневмонію та встановлення фармакологічної ефективності комплексних антигомотоксичних препаратів Траумель (ad us.vet) та Фосфор-Гомаккорд (ad us.vet). Матеріалом для дослідження були 40 собак віком від 1 до 3 років, масою тіла від 34 до 43 кг (німецька та східно-свропейська вівчарка), хворих на гостру катаральну бронхопневмонію. Кожна тварина піддавалася клінічним та гематологічним дослідженням. В результаті проведених досліджень було встановлено, шо застосування комплексної антигомотоксичної терапії є терапевтично доцільним і ефективним в порівнянні з традиційною mерапією.

Ключові слова: катаральна бронхопневмонія, Траумель, Фосфор-Гомаккорд, антигомотоксична терапія, лімфотропне введення, наслідки лікування, резистентність організму, фармакологічний ефект, побічний ефект, собаки, клінічне дослідження, гематологічне дослідження.
\end{abstract}

\section{Оценка фармакологической эфективности траумеля (ad us.vet) и фосфора-гомаккорд (ad us.vet) при бронхопневмонии собак}

\author{
Ю.А. Чубов, В.Ю. Кушнир \\ ogsi@te.net.ua
}

Одесский государственный аграрный университет, ул. Пантелеймоновская, 13, г. Одесса, 65012, Украина

\begin{abstract}
Слизистая оболочка респираторного тракта легко поддается непосредственному воздействию окружающей среды, контактируя с вдыхаемым воздухом, по этому бронхопневмония у собак встречается часто. Для терапии собак, больных катаральной бронхопневмонии, существует значительное количество средств и методов, но они не всегда эффективны. Более того, значительная часть этих методов обладает длительным периодом ожидания действия и большим количеством побочных эффектов. Поэтому иелью наших исследований был поиск эффективного и биологически безопасного метода лечения собак, больных катаральной бронхопневмонии и установление фармакологической эффективности комплексных антигомотоксических препаратов Траумель (ad us.vet) и Фосфор-Гомаккорд (ad us.vet). Материалом для исследования были 40 собак в возрасте от 1 до 3 лет, весом от 34 до 43 кг (немеикий и восточно-европейская овчарка), больных острой катаральной бронхопневмонией. Каждое животное подвергалась клиническим и гематологическим исследованиям. В результате проведенных исследований было установлено, что применение комплексной антигомотоксической терапии терапевтически целесообразным и эффективным по сравнению с традиционной терапией.
\end{abstract}

\section{Citation:}

Chubov, Yu.O., Kushnir, V.Yu. (2016). The evaluation of the action of complex anthyhomotoxyk preparations traumel (ad us.vet) and phosphorhomaccord (ad us.vet) in bronchopneumonia of dogs. Scientific Messenger LNUVMBT named after S.Z. Gzhytskyj, 18, 2(66), $206-211$. 
Ключевые слова: катаральная бронхопневмония, Траумель, фосфор-гомаккорд, антигомотоксическая терапия, лимфотропной ввода, результаты лечения, резистентность организма, фармакологический эффект, побочный эффект, собаки, клиническое исследование, гематологическое исследование.

\title{
The evaluation of the action of complex anthyhomotoxyk preparations traumel (ad us.vet) and phosphor-homaccord (ad us.vet) in bronchopneumonia of dogs
}

\author{
Yu.O. Chubov, V.Yu. Kushnir \\ ogsi@te.net.ua \\ Odessa State Agrarian University, \\ Panteleimonovska Str., 3, Odessa 65012, Ukraine
}

\begin{abstract}
The mucous membrane of the respiratory tract is easily the immediate effects of the environment, while contact with air that is inhaled, so pneumonia is common in dogs. For the treatment of dogs, sick with catarrhal bronchopneumonia there are a number of tools and methods, but they are not always effective. Moreover, many of these methods have long waiting period of action and significant side effects. Thet is why the purpose of our research work was to find effective and biologically safe treatment of dogs, sick with catarrhal bronchopneumonia and installation pharmacological effectiveness of complex antihomotoxic preparations Traumel (ad us.vet) and Phosphor-Homakkord (ad us.vet). The material for the study were 40 dogs aged 1 to 3 years old, weighing 34 to $43 \mathrm{~kg}$ (German and East-European sheep-dog), sick with acute catarrhal bronchopneumonia. Each animal was subjected to clinical and hematology research. Sick animals were divided in to four groups: ten animals to each group. First and second - control groups, third and fourth - experimental groups. In the first group we used mukaltyn $0.5 \mathrm{~g}$ orally twice a day up to recovery, bitsillin $350 \mathrm{th}$. UA / $\mathrm{kg}$ once every three days by intramuscular injection, dissolving in $2 \mathrm{ml}$ of isotonic sodium chloride and vitamin $B 121 \mathrm{ml}$ once a day subcutaneously for 10 days. In the second control group instead of bitsillin-3 was used antibiotic combi-kell $1 \mathrm{ml} \mathrm{per} 10 \mathrm{~kg}$ weight of body subcutaneously once every three days up to recover.
\end{abstract}

In the third and fourth groups we used the lymphotropic complex antihomotoxic therapy with using the homeopathic preparations Traumel and Phosphor-Homakkord in conjunction with traditional means. Thus, in the third group was used inside mukaltyn $0.5 \mathrm{~g}$ twice a day up to recovery, bitsillin $350 \mathrm{th}$. UA / $\mathrm{kg}$ once every three days vnutrishom'yazovo dissolving in $2 \mathrm{ml}$ of isotonic sodium chloride lidasa intradermally $32 \mathrm{IU}$ with $1 \mathrm{ml}$ of $0.5 \%$ solution of novocaine 3 days in a row, then 3 times a week, Traumel regional lymphotropic three consecutive days to $1 \mathrm{ml}$ intradermally, then every three days and Phosphor-Homakkord lymphotropic regionally $1 \mathrm{ml} 1$ every 3 days to recovery. In the fourth experimental group used the same treatment, but instead of bitsillin-3 was used Combi-Kell $1 \mathrm{ml} / 10 \mathrm{~kg}$ subcutaneously once every three days to recover.

The results of our researches show that using of complex anthyhomotoxic therapy is appropriate and therapeutically effective versus conventional therapy.

So despite the fact that there are a wide number of preparations and methods for treatment of dogs, sick with catarrhal bronchopneumonia, they are not always effective. As shown by our researches, using of compex anthyomotoxic lymphotropic with the preparations Traumel and Phosphor-Homakkord reduces the duration and improve the quality of treatment.

Key words: catarrhal bronchopneumonia, Traumel, Phosphor-Homakkord, Anthyhomotoxic therapy, lymphotropic injection, the effects of treatment resistance, pharmacological effects, side effects, dogs, clinical research, hematology research.

\section{Вступ}

В зв'язку з тим, що слизова оболонка респіраторного тракту легко піддається безпосередньому впливу навколишнього середовища, контактуючи із повітрям, яке вдихається, часто зустрічається бронхопневмонія у тварин, і зокрема у собак. При цьому потрапляння різних хімічних речовин, мікроорганізмів (бактерії, віруси, гриби), що мають різний ступень токсичності, патогенності і вірулентності, цьому сприяє. Тому, при зниженні імунітету, слизова оболонка дихальної системи в першу чергу є сприятливим середовищем для існування і розмноження патогенних мікроорганізмів.

Провідним механізмом при цьому $є$ запальний процес, який починається в слизовій оболонці бронхів у відповідь на дію зовнішніх патогенних факторів. При цьому відбувається зміна функції секреторного апарата (гіперсекреція слизу, зміна бронхіального секрету), активізується патогенна мікрофлора, розвивається комплекс реакцій, що призводить до пошкодження бронхів і альвеол, що до них прилягають. Порушення стану протеолітичних ферментів та антипротеаз, вади антиоксидантного захисту легень ускладнюють пошкодження (Kondrahin et al., 1985).
Персистуюча колонізація нижніх дихальних шляхів патогенною мікрофлорою, зниження активності місцевих механізмів захисту і підсилення негативної післядії оксидантного стреса сприяє дестабілізації функціональної активності клітин слизової оболонки бронхів. Підсилення при цьому запального процесу і блокада шляхів лімфатичного дренажа бронхіальної стінки обумовлює погіршення бронхіальної прохідності, що негативно впливає на легеневу вентиляцію (Verbyc'kyj and Dostojevs'kyj, 2004; Kanjuka et al., 2006).

Депресія основних механізмів антиоксидантного захисту на тлі надмірного утворення ендогенних токсичних речовин і виснаження механізмів саморегуляції супроводжується порушенням окисно-відновних процесів на клітинному рівні в слизовій оболонці бронхіального дерева. Ріст дистрофічнодеструктивних процесів, низька функціональна активність мукоціліарного апарату, пригнічення фагоцитозу відбувається при постійному надходженні екзогенних гомотоксинів, що сприяє каскадному утворенню ендогенних джерел вільних радикалів. За таких умов запальні і імунні пошкодження слизової оболонки бронхіального дерева набувають безперервно ре- 
цидивуючий характер. Швидкість прогресування і виразність хвороби багато в чому залежить від інтенсивності дії екологічних факторів та їх сумації.

Для терапії собак, хворих на катаральну бронхопневмонію, існує значна кількість лікарських речовин (в основному хімічного походження) і методів, але вони не завжди $\epsilon$ ефективними. В практиці ветеринарної медицини не можна обійтись без антибіотиків, якщо мова йде про життя і смерть тварини, для запобігання i лікування хворих з запальними процесами, які викликані бактеріальною мікрофлорою. При цьому не існує жодного антибіотика, який не завдав би в тому чи іншому ступені побічних реакцій і ускладнень. Окрім згубної дії на мікроорганізми, антибіотики можуть завдавати несприятливий вплив і на організм хворого. Побічні ефекти, які обумовлені антимікробними препаратами, поділяються на три групи, в залежності від механізму дії цих препаратів:

1) алергічна реакція (від легких шкірних реакцій до анафілактичного шоку з летальним наслідком);

2) прямі токсичні реакції у вигляді токсичного ураження нирок, печінки, травного тракту, нервової і кровотворної систем;

3) реакції, що відбуваються за рахунок біологічних змін мікроорганізмів або мікробних агентів (утворення фармакологічно стійких штамів збудників, суперінфекція, дизбактеріоз).

Можливе також і пригнічення імунних реакцій, розлад вітамінного і електролітного обміну і т.д. Найбільш частим ускладненням антибіотикотерапії $є$ дизбіоз кишечника або стійкі зміни співвідношення нормальної і патологічної мікрофлори шлунковокишкового тракту. Мікрофлора відіграє при цьому суттєву роль в імунорегуляції і збереженності здоров'я тварини. Клінічна картина прояву дизбіозу кишечника частіше всього пов'язана з ураженням слизової оболонки травного тракту, порушенням його моторної, всмоктуючої і евакуаторної функції. При дизбіозі виникає послаблення захисних сил організму, підвищується сприйнятливість до інфекційних захворювань і ризик розвитку алергічних реакцій.

Тому ведеться активний пошук лікарських речовин біологічного, природного походження, які здатні впливати на метаболічні процеси, рівень адаптації, стійкість до захворювань і, разом з тим, мінімізувати побічні ефекти.

Причому, немає таких алопатичних ліків, які б не володіли потенційною або помітною побічною реакцією. У зв'язку з цим пошук біологічної терапії $є$ дуже актуальним.

Гомотоксикологія - це напрямок сучасної біологічної медицини, що розглядає організм як цілісну систему, що перебуває в динамічній рівновазі. При взаємодії з гомотоксинами (екзо - або ендогенними) система починає проявляти захисну реакцію, спрямовану на запобігання або зменшення до мінімуму їх дії.

3 погляду гомотоксикології всі хвороби, у тому числі і катаральна бронхопневмонія собак, є біологічно цілеспрямованими корисними процесами. Вони являють собою біологічно адекватні прояви захисної системи організму, які намагаються відсторонити або компенсувати шкідливу дію, викликану токсинами.
Тому, головна роль в антигомотоксичному захисті приділяється запальному процесу (Chubov, 2002; Chubov and Najdich, 2006).

Знешкодження токсинів в організмі здійснюється в основному печінкою і нирками шляхом складних біохімічних реакцій з подальшим їх виведенням. Біологічне лікування, що запропоноване гомотоксикологією, направлено на те, щоб викликати або активізувати процеси зв'язування і виведення. Активізація цих процесів при гострому запаленні дозволяє організму швидко впоратися з порушеннями і відновитися.

У доступній нам літературі недостатньо інформації про застосування антигомотоксичних препаратів у собак при катаральній бронхопневмонії, тобто про застосування принципів гомотоксикології - ініціювання, регулювання, відновлення всіх систем організму і обміну речовин. Існують окремі повідомлення про комплексну антигомотоксичну терапію у гуманній медицині при пневмонії у дітей і у ветеринарній медицині - при бронхопневмонії поросят і телят (Chubov, 2002; Chubov and Najdich, 2006).

Мета $і$ завдання дослідження. Метою роботи $€$ пошук ефективної комплексної біологічно нешкідливої регіональної лімфотропної антигомотоксичної терапії при катаральній бронхопневмонії собак і проведення оцінки фармакологічної ефективності антигомотоксичних препаратів Траумель (ad us.vet) та Фосфор-Гомаккорд (ad us.vet). Завданнями дослідження було:

1. Встановити клінічний діагноз

2. Визначити чутливість мікрофлори до антибіотиків

3. Провести регіональну лімфотропну терапію

4. Встановити фармакологічний ефект комплексних антигомотоксичних препаратів Траумель (ad us.vet) та Фосфор-Гомаккорд (ad us.vet) при лікуванні собак, хворих на гостру катаральну бронхопневмонію.

\section{Матеріал і методи дослідження}

Матеріалом для дослідження були 40 собак породи віком від 1 до 3 років, масою тіла від 34 до 43 кг (німецька та східно-свропейська вівчарка), хворих на катаральну бронхопневмонію. У тварин спостерігалися характерні ознаки катаральної бронхопневмонії: хрипи, легеневі витікання 3 носової порожнини, кашель, що підсилюється при русі, вогники притуплення в окремих ділянках.

В залежності від методів лікування хворі тварини були розділені на чотири групи по 10 тварин у кожній: 1 і 2 - контрольні (традиційні методи); 3 і 4 дослідні (нетрадиційні методи). До лікування з метою визначення чутливості мікрофлори до антибіотиків провели титрування. У першій групі використали мукалтин 0,5г всередину два рази на добу до одужання, біцилін 350 тис.ОД/кг один раз у три дні внутрішньом'язово, розчиняючи в 2 мл ізотонічного розчину натрію хлориду та вітамін $\mathrm{B}_{12} 1$ мл один раз за добу підшкірно протягом 10 діб. У другій контрольній групі замість біциліну-3 був застосований антибіотик комбі-кель по 1 мл на 10 кг масси тіла підшкірно один раз на три дні до одужання. 
У третій та четвертій групах ми застосували комплексну антигомотоксичну лімфотропну терапію 3 використанням гомеопатичних препаратів Траумель та Фосфор-Гомаккорд у поєднанні 3 традиційними засобами. Так, у третій групі було застосовано мукалтин 0,5 г усередину два рази на добу до одужання, біцилін 350 тис.ОД/кг один раз у три дні внутрішьом'язово, розчиняючи в 2 мл ізотонічного розчину натрію хлориду, лідаза внутрішньошкірно 32 ОД з 1 мл $0,5 \%$ розчину новокаїну 3 доби підряд, потім 3 рази на тиждень, Траумель лімфотропно регіонально три дні підряд по 1 мл внутрішньошкірно, потім раз у три дні та Фосфор-Гомаккорд лімфотропно регіонально по 1 мл 1 раз на 3 доби до одужання. У четвертій дослідній групі застосували таке ж лікування, але замість біциліну-3 був використаний Комбі-Кель 1 мл/10 кг підшкірно один раз у три дні до одужання.

Причьому, в дослідних групах ми застосували регіональне лімфотропне введення. Цей метод заснований на здатності лімфатичних капілярів шкіри розширюватися під дією деяких ферментних препаратів, зокрема лідази, і підсилені поглинання ділянкою шкіри рідини і препаратів, що знаходяться в ній.

Як відомо, лідаза викликає зворотній розпад глікозаміноглікану (мукополісахариду) - гіалуронової кислоти до глюкозаміну і глюкорової кислоти. Гіалуронова кислота в організмі $є$ цементуючою речовиною сполучної тканини, тому при iї розпаді збільшується проникність тканин, прискорюються процеси дифузії через тканинні мембрани і поліпшується рух рідини в міжтканинних просторах. Дія гіалуронідази інша - при зменшенні їі концентрації в'язкість гіалуронової кислоти відновлюється.

Причому послідовність дії при цьому враховує вибір місця ін'єкції, який залежить від вогнища запалення; підготовку місця ін'єкції (ви-далення шерстяного покриву на ділянці шкіри $15 \times 15$ мм і обробка їі спиртом), внутрішньошкірне введення розчину лідази 32 УО $з$ 0,5\% розчином новокаїну (1 мл), введення анигомотоксичного препарату $1 / 2$ однократної терапевтичної дози (у теж місце через п'ять хвилин після введення лідази). Нижче наведена коротка характеристика комплексних антигомотоксичних препаратів Траумель і Фосфор-Гомаккорд.

\section{Tраумель (для ветеринаріi) - Traumeel ad us. vet.}

Склад: розчин для ін'єкцій: 5 мл містить: Aconitum napellus D4 0,3 ml; Aristolochia clematitis D11 0,25 ml; Arnica montana D4 0,5 ml; Atropa belladonna D4 0,5 ml; Bellis perennis D4 0,25 ml; Calendula D4 0,5 ml; Chamomilla D5 0,5ml;Echinacea angustifola D4 0,125 $\mathrm{ml}$; Echinacea purpurea e planta tota D4 $0,125 \mathrm{ml}$; Hamamelis D3 0,05 ml; Hypericum D4 0,15 ml; Millefolium D5 0,5 ml; Symphytum D8 0,5 ml; Hepar sulfuris D6 0,5 ml; Mercurius solubilis Hahnemanni D8 $0,125 \mathrm{ml}$ Traumeel $\mathrm{S}$, розчин для ін'єкцій: 2,2 мол містять: Arnica D2, Calendula D2, Chamomilla D3, Symphytum D6, Millefolium D3, Belladonna D2по 2,2 мкл кожного; Aconitum D2 1,32 мкл; Bellis perennis D2 1,1 мкл; Hypericum D2 0,66мкл; Echinacea anqustifolia D2, Echinacea purpurea D2 nо 0,55 мкл кожного; Hamamelis D1 no 0,22 мкл; Mercurius solubilis Hahnemanni D6 1,1 мг; Hepar sulfuris D6 2,2 мкл.
Коротка характеристика окремих компонентів рецептури препарату Traumeel ad us. vet.:

Arnica Montana (арніка гірська, бараняча трава) кровотечі, захворювання артеріальної й венозної систем, шок.

Calendula (календула) - рани що погано загоюються, опіки, рвано-забиті рани.

Hamamelis (гамамеліс вергінський) - венозний застій, кровотечі зі шкіри й слизових оболонок.

Aconitum napellus (борець) - гострі запальні захворювання, ранозаживляючий i знеболюючий засіб, зупинка кровотеч.

Aristolochia clematitis (киркозон ломоносовидний) - міхурцеве висипання, екземи із сильною сверблячкою, набряки кінцівок, болі в суглобах.

Atropa belladonna (беладона) - пропасні стани, запальні процеси в шкірі та суглобах, а також у легенях і молочних залозах.

Bellis perennis (маргаритка) - кровотечі й крововиливи, м'язові болі пов'язані з перенапругою.

Chamomilla (ромашка) - гострий біль, збудження.

Echinacea angustifolia (ехінацея вузколистна) - терапія важких форм інфекційних ураень (стимуляція імунітету)

Echinacea purpurea (ехінацея пурпурна) - терапія важких форм інфекційних поразок (стимуляція імунітету)

Нуреricum (звіробій) - знеболюючий регенеруючий засіб при ураженні центральної й периферичної нервової системи.

Millefolium (деревій) - кровотечі, болі при судомах, нормалізація картини протромбінів.

Symphytum (окопник) - ураження кістки і окістя (знеболююча та регенеруюча дія).

Hepar sulfuris (сірчана печінка) - гнійні запалення шкіри і слизових оболонок. Регуляція окислювальновідновних процесів.

Mercurius solubilis Hahnemanni (розчинний закис ртуті) - запалення слизових оболонок, підвищення імунітету при вірусних інфекціях. vet.)

Фосфор-Гомаккорд (Phosphor Homaccord ad us.

Гомеопатичний лікарський засіб для застосування у ветеринарній медицині.

Склад:

1 ампула 5 мл. містить: Phosphorus D10, D30, D200 ana $0,02 \mathrm{ml}$; Argentum nitricum D10, D30, D200, Paris quadrifolia D10, D30, D200 ana 0,015 ml.

Показання:

Захворювання паренхіми, діатез 3 кровотечею, ураження органів слуху, рахіт, остеомаляція, тетанус, бронхопневмонія, фарингіт, хронічні гнійні хвороби, дерматопатія, невроз, порушення поведінки.

Протипоказання, побічні ефекти: відсутні.

Взаємодія з іншими засобами: без особливостей.

Період очікування ефекту: відсутній.

Коротка характеристика показань окремих складових препарату:

Phosphorus:

запалення дихальних шляхів (трахеїт, ларингіт в поєднанні з хрипотою), кровотечі.

Argentum nitricum: 
захворювання шлунково-кишкового тракту, фарингіт, ларингіт 3 хрипотою, інші ураження слизової оболонки.

Paris quadrifolia:

запалення дихальних шляхів у поєднанні 3 хрипотою.

\section{Результати та їх обговорення}

Результати дослідження показали, що найкращий ефект дає лікування 3 застосуванням комплексної антигомотоксичної терапії(таблиця 1).

3 метою підтвердження клінічного діагнозу і спостереження за ефективністю лікування собак, хворих на катаральну бронхопневмонію, ми проводили гематологічні дослідження до лікування, в процесі лікування та на момент одужання. При цьому визначали вміст гемоглобіну, лейкоцитів та швидкість осідання еритроцитів (таблиця 2,3,4). Ці показники в поєднанні 3 клінічною картиною дають можливість говорити про реактивність організму, ступінь його захисних функцій а також дозволяють своєчасно діагностувати та прогнозувати кінець хвороби. Окрім того, для порівняння даних, отриманих при дослідженні крові у хворих тварин, нами було проведене дослідження крові у двадцяти клінічно здорових тварин.

Результати комплексної терапії

\begin{tabular}{|c|c|c|c|c|c|}
\hline \multirow{2}{*}{ Групи } & \multirow{2}{*}{$\begin{array}{c}\text { Кількість } \\
\text { тварин }\end{array}$} & $\begin{array}{c}\text { Тривалість ліку- } \\
\text { вання (діб) }\end{array}$ & Одужало & $\begin{array}{c}\text { Перейшло в хроніч- } \\
\text { ний перебіг }\end{array}$ & Загинуло \\
\hline I & 10 & $17-19$ & 7 & 2 & 1 \\
\hline II & 10 & $18-20$ & 8 & 1 & 1 \\
\hline III & 10 & $10-12$ & 9 & 1 & - \\
\hline IV & 10 & $11-13$ & 8 & 2 & - \\
\hline
\end{tabular}

Таблиця 2

Вміст гемоглобіну, г/л (середній показник у клінічно здорових тварин - 127)

\begin{tabular}{|c|c|c|c|c|}
\hline \multirow{2}{*}{ Група тварин } & \multirow{2}{*}{ Кількість тварин } & \multicolumn{3}{|c|}{ Дні досліду } \\
\hline & & 1-й день & 10-й день & 20-й день \\
\hline I & 10 & $131 \pm 0,02$ & $128 \pm 0,03$ & $130 \pm 0,05$ \\
\hline II & 10 & $139 \pm 0,04$ & $131 \pm 0,03$ & $136 \pm 0,04$ \\
\hline III & 10 & $138 \pm 0,03$ & $132 \pm 0,04$ & $138 \pm 0,05$ \\
\hline IV & 10 & $135 \pm 0,04$ & $130 \pm 0,05$ & $139 \pm 0,06$ \\
\hline
\end{tabular}

Вміст лейкоцитів, Г/л (середній показник у клінічно здорових тварин - 8,7)

Таблиця 3

\begin{tabular}{|c|c|c|c|c|}
\hline \multirow{2}{*}{ Група тварин } & \multirow{2}{*}{$\begin{array}{c}\text { Кількість } \\
\text { тварин }\end{array}$} & $1-$ й день & $10-$ й день & $20-$ й день \\
\cline { 3 - 5 } & 10 & $17,2 \pm 0,03$ & $14,1 \pm 0,03$ & $10,9 \pm 0,03$ \\
\hline I & 10 & $17,3 \pm 0,03$ & $11,4 \pm 0,03$ & $9,8 \pm 0,03$ \\
\hline II & 10 & $17,5 \pm 0,04$ & $10,2 \pm 0,03$ & $7,2 \pm 0,03$ \\
\hline III & 10 & $17,4 \pm 0,03$ & $10,5 \pm 0,04$ & $7,8 \pm 0,03$ \\
\hline IV & &
\end{tabular}

Швидкість осідання еритроцитів, мм/год (середній показник у клінічно здорових тварин -4)

\begin{tabular}{|c|c|c|c|c|}
\hline \multirow{2}{*}{ Група тварин } & \multirow{2}{*}{$\begin{array}{c}\text { Кількість } \\
\text { тварин }\end{array}$} & \multicolumn{3}{|c|}{ Дні досліду } \\
\hline & & 1-й день & 10-й день & 20-й день \\
\hline $\mathrm{I}$ & 10 & $8 \pm 0,03$ & $7 \pm 0,03$ & $6 \pm 0,03$ \\
\hline II & 10 & $9 \pm 0,02$ & $8 \pm 0,04$ & $5 \pm 0,04$ \\
\hline III & 10 & $10 \pm 0,02$ & $6 \pm 0,03$ & $3 \pm 0,03$ \\
\hline IV & 10 & $10 \pm 0,02$ & $7 \pm 0,03$ & $4 \pm 0,04$ \\
\hline
\end{tabular}

При аналізі даних, отриманих в результаті гематологічних досліджень ми спостерігаємо у хворих собак тенденцію до зниження гемоглобіну і підвищення кількості лейкоцитів та швидкості осідання еритроцитів. В процесі лікування і до двадцятого дня досліду у тварин, що одужали відбувається нормалізація вищеназваних показників. Особливо наочно це відбувається при антигомотоксичній терапії, де вміст гемоглобіну був вищим, а кількість лейкоцитів та швидкість осідання еритроцитів - нижче, ніж у собак контрольної групи.

\section{Висновки}

Таким чином не дивлячись на те, що існує значна кількість засобів і методів лікування собак, хворих на катаральну бронхопневмонію, вони не завжди є ефективними. Як показали наші дослідження, застосування комплексної антигомотоксичної лімфотропної терапії 3 використанням препаратів Траумель (ad us.vet) та Фосфор-Гомаккорд (ad us.vet) сприяє зменшенню тривалості та підвищенню якості лікування, що свідчить про позитивну фармакологічну ефективність даних препаратів. 
Перспективи подальших досліджень. В подальшому можливі дослідження ефективності застосування даних препаратів при катаральній бронхопневмонії на більшій кількості тварин і не тільки в Одесі, а й в цілому на Півдні України.

\section{Бібліографічні посилання}

Verbyc'kyj, P.I., Dostojevs'kyj, P.P. (2004). Dovidnyk likarja veterynarnoi' medycyny. K.: Urozhaj (in Ukrainian).

Kanjuka, O.I., Fajtel'berg-Blank, V.R., Lyzogub, Ju.P. (2006). Klinichna veterynarna farmakologija. Odesa: Astroprynt (in Ukrainian).

Kondrahin, I.P., Kurilov, N.V., Malahov, A.G. (1985). Klinicheskaja laboratornaja diagnostika $\mathrm{v}$ veterinarii. M.: Agropromizdat (in Russian).
Chubov, Ju.A. (2002). Jeksperimental'noe obosnovanie primenenija antigomotoksicheskih preparatov pri kataral'noj bronhopnevmonii porosjat: avtoref. diss... d-ra. veter. nauk: 16.00.01. Sankt-Peterburgskaja gosudarstvennaja akademija veterinarnoj mediciny (in Russian).

Chubov, Ju.A., Najdich, O.V. (2006). Sovremennaja traktovka patogeneza kataral'noj bronhopnevmonii $\mathrm{s}$ pozicii gomotoksikologii [Tekst]: materialy XIV Moskovskogo mezhdunarodnogo veterinarnogo kongressa. Moskva (Rossija), 34-35 (in Russian).

Стаття надійшла до редакиії 29.09.2016 